УДК $338.001 .36+655$

JEL classification: E2, E4, L1, O11

Гавриш Ю.О.

ORCID ID: 0000-0003-3639-9001

Кухарук А. Д.

канд. економ. наук, дочент, ORCID ID: 0000-0003-1454-0369

Національній технічний університет Україні «Київський політехнічний інститут імені Ігоря Сікорського»

\title{
ВИЗНАЧЕННЯ ДЕТЕРМІНАНТІВ ПІДВИЩЕННЯ КОНКУРЕНТОСПРОМОЖНОСТІ ВИДАВНИЧО-ПОЛІГРАФІЧНИХ ПІДПРИЕМСТВ
}

\section{IDENTIFICATION OF DETERMINANTS OF INHANCING THE COMPETITIVENESS OF PUBLISHING AND PRINTING COMPANIES}

Статтю присвячено аналізу основних детермінантів формування конкурентних переваг видавничо-поліграфічними підприємствами. Визначено умови, за яких виникає можливість підвищення рівня конкурентоспроможності суб'єктів видавничополіграфічної діяльності. Визначено, щяо основними детермінантами конкурентоспроможності таких підприємств є макроекономічні та фінансові, котрі у свою чергу щільно пов'язані із ресурсним забезпеченням конкурентного потенціалу компаній та сприяють посиленню їх позииї на ринку. Проаналізовано макроекономічні чинники розвитку підприємств в Україні та світі, охарактеризовано основні тендениіі виробничо-комериійної діяльності поліграфічних підприємств з урахуванням їх ділових очікувань. Проаналізовано макроекономічні показники України, основні показники діяльності підприємств України та виявлено позитивні чинники формування та реалізачіі конкурентних переваг видавничо-поліграфічних підприємств. Зазначено, щзо саме фінансовий чинник визначає можливість економічного прочвітання більшості видавничополіграфічних підприємств світу. Разом з тим, виявлено зростання витрат на операційну діяльність поліграфічних компаній протягом останніх років, у тому числі друкарень та постачальників поліграфічних матеріалів. Проаналізовано структуру операчійних витрат видавничо-поліграфічних підприємств. Зауважено, щзо задля підвищення конкурентоспроможності, зокрема при реалізачії конкурентної стратегї лідерства за витратами, доцільним є пошук иляхів оптимізачії витрат на матеріальне забезпечення та формування фонду заробітної плати. Проведено аналіз рівня заробітних плат на поліграфічних підприємствах. Узагальнено можливі напрями оптимізації обсягу фонду заробітної плати з урахуванням доиільності реорганізації робочих груп. Перспективним напрямом подальших досліджень є очінювання економічної ефективності створення дистанційних проектних команд на видавничо-поліграфічних підприємствах з метою протидіi негативному впливу фінансових чинників-дестимуляторів конкурентоспроможності.

Ключові слова: видавничо-поліграфічне підприємство; поліграфічна діяльність, детермінанти конкурентоспроможності; макроекономічні показники; фінансові чинники конкурентоспроможності 
The article is devoted to the analysis of the main determinants of the formation of ccompetitive advantages by publishing and printing companies. The article determines the conditions for increasing the level of competitiveness of publishing and printing companies. The authors notice that the main determinants of the competitiveness of such enterprises are macroeconomic and financial ones, which are closely related to the resource support of the competitive potential of companies and help to strengthen their position in the market. The macroeconomic factors of the development of enterprises in Ukraine and the world analyzed in the article. The study describes main tendencies of production and commercial activity of printing industry taking into account companies' business expectations. The macroeconomic indicators of Ukraine as well as main indicators of activity of Ukrainian enterprises are analyzed, and positive factors of formation and realization of competitive advantages of publishing and printing enterprises are revealed. The authors note that it is the financial factor that determines the possibility of economic prosperity for most publishing and printing companies in the world. At the same time, the growth of expenses for the operations of printing companies in recent years, including printers and suppliers of printing materials, has been noted. The structure of operating expenses of publishing and printing enterprises is analyzed. It is noted that in order to increase competitiveness, in particular when implementing a competitive strategy for cost leadership, it is expedient to find ways to optimize the cost of material provision and the formation of a wage fund. An analysis of the level of wages at printing companies was conducted. The possible directions of optimization of the wage fund volume are generalized, taking into account the expediency of reorganization of working groups. A promising direction for further research is the evaluation of the cost-effectiveness of creating remote project teams at publishing and printing companies in order to counteract the negative impact of financial factors-disincentives of competitiveness.

Keywords: publishing and polygraphic enterprise; printing activity, determinants of competitiveness; macroeconomic indicators; financial factors of competitiveness

Вступ. Забезпечення високого рівня конкурентоспроможності за рахунок створення стійких конкурентних переваг є однією 3 важливих задач стратегічного управління видавничо-поліграфічними підприємствами, котрі у свою чергу забезпечують комерційний успіх багатьох інших галузей промисловості, надаючи послуги з друку рекламно-сувенірної продукції та видань маркетингового призначення. Проте виконання цього завдання може суттєво ускладнюватись в умовах економічної нестабільності та невизначеності, що зумовлюють необхідність пошуку нових інструментів підвищення конкурентоспроможності та передбачення можливих негативних чинників впливу на економічну стійність видавничо-поліграфічних підприємств. Тому дослідження детермінантів конкурентоспроможності таких підприємств $є$ актуальним науковим завданням, що визначає своєчасність та доцільність даного дослідження.

Внесок в удосконалення науково-методичних аспектів управління рівнем конкурентоспроможності видавничо-поліграфічних підприємств здійснили такі автори: О. А. Гавриш [19], С. О. Солнцев [20], Б. В. Дурняк, А. М. Штангрет, О. В. Мельников [21], Л. Є. Довгань [22], С. М. Палига [23] та ін. Вченими створено теоретико-методологічне підгрунтя визначення рівня конкурентоспроможності підприємств, факторів та імпульсів забезпечення конкурентних переваг, інструментарію управління конкурентною позицією поліграфічних підприємств. Разом 3 тим, 
залишаються такими, що потребують подальшого розвитку наукові положення 3 обгрунтування детермінантів конкурентоспроможності видавничо-поліграфічних підприємств в умовах нестабільності економічного середовища.

Постановка завдання. Метою статті $\epsilon$ розвиток теоретичних та прикладних аспектів визначення детермінантів підвищення конкурентоспроможності видавничо-поліграфічних підприємств в умовах економічної нестабільності. Задля досягнення поставленої мети визначено та вирішено наступне завдання: узагальнити особливості макроекономічного та фінансового забезпечення підвищення конкурентоспроможності видавничополіграфічних підприємств.

Методологія. Методологічною основою стали наукові праці вітчизняних i зарубіжних учених, статистичні дані, дані міжнародних аналітичних звітів, офіційних галузевих професійних інтернет-порталів. У дослідженні використано методи наукового порівняння, конкретизації, спеціальні графічні методи для наочного представлення результатів, методи аналізу та синтезу використано задля формулювання та обгрунтування висновків.

Результати дослідження. Проведений аналіз специфіки функціонування видавничо-поліграфічної галузі надає підстави стверджувати, що основними групами чинників, які можуть вважатись детермінантами конкурентоспроможності підприємств галузі $\epsilon$ такі: макроекономічні, фінансові, інформаційні та техніко-технологічні. У межах даної статті висвітлено результати аналізу перших двох груп детермінантів макроекономічних та фінансових.

I. Макроекономічні детермінанти. У ході дослідження, результати якого опубліковано у [4] виявлено, що одним із чинників підвищення конкурентоспроможності підприємств $є$ рівень макроекономічної нестабільності. Факторами найбільшого впливу, котрі стримують розвиток бізнесу в Україні у 2017-2018 рр., на думку експертів Світового економічного форуму, є інфляція, корупція та політична нестабільність [5, с. 296].

Аналізуючи звітні матеріали Державної служби статистики України, зокрема, результати опитування підприємств щодо їх ділових очікувань [3], можна зробити наступні висновки:

- суб'єкти господарювання прогнозують підвищення ринкових цін на товари та послуги;

- очікується зменшення кількості працівників на підприємствах сфери послуг та посилення залежності операційної діяльності від фактора нестачі робочої сили;

- прогнозується зниження попиту на послуги в середньому на $1 \%$.

- за результатами самооцінювання більшість (60 \%) опитаних підприємств очікує, що їх конкурентна позиція на внутрішньому та зовнішніх ринках не зміниться; меншість респондентів передбачає посилення 
конкурентної позиції (на внутрішньому ринку - 8 \% відповідей; на ринку ЄС - 1 \% відповідей);

- в цілому, підприємці мають оптимістичні очікування на найближчі 12 місяців щодо фінансового стану та нарощення інвестицій.

Також, згідно даних аналітичного звіту “Doing Business 2019” [1, с. 5], в Україні покращилися умови ведення бізнесу: серед 190 країн світу за показником легкості ведення бізнесу, поступаючись Киргизькій Республіці та випереджаючи Грецію, Україна посіла 71 позицію, що на 5 позицій вище, порівняно із попереднім періодом [2, с. 4].

Разом 3 тим, задля оцінювання макроекономічної ситуації в Україні доцільно проаналізувати динаміку основних макроекономічних показників на основі даних табл. 1.

Таблиця 1 - Розрахункові значення основних макроекономічних показників України за період 2010-2018 рр.

\begin{tabular}{|c|c|c|c|c|c|c|c|c|c|c|}
\hline \multirow{2}{*}{$\begin{array}{l}\text { № } \\
\text { П/П }\end{array}$} & \multirow{2}{*}{ Показник } & \multicolumn{9}{|c|}{ Роки } \\
\hline & & 2010 & 2011 & 2012 & 2013 & 2014 & 2015 & 2016 & 2017 & $2018^{*}$ \\
\hline 1 & $\begin{array}{l}\text { ВВП на душу населення, } \\
\text { тис. грн }\end{array}$ & 23,6 & 28,8 & 30,9 & 31,9 & 35,8 & 46,2 & 55,8 & 70,2 & 59,3 \\
\hline 2 & Рівень безробіття, \% & 8,8 & 8,6 & 8,1 & 7,7 & 9,7 & 9,5 & 9,7 & 9,9 & 9,4 \\
\hline 3 & $\begin{array}{l}\text { Індекс інфляції, \%, } 2008 \\
\text { р.=100 \% }\end{array}$ & 149,9 & 156,7 & 156,4 & 157,2 & 196,2 & 281,2 & 316,0 & 359,2 & 391,2 \\
\hline 4 & $\begin{array}{l}\text { Індекс цін } \\
\text { промислової } \\
\text { (грудень продукікії } \\
\text { попереднього року, груд) }\end{array}$ & 20,9 & 19,0 & 3,7 & 1,7 & 31,8 & 25,4 & 35,7 & 16,5 & 14,2 \\
\hline \multirow[t]{7}{*}{5} & $\begin{array}{c}\text { Середня заробітна плата } \\
\text { працівника, тис. грн.: } \\
\text { Зокрема у галузях: }\end{array}$ & 2,3 & 2,6 & 3,0 & 3,3 & 3,5 & 4,2 & 5,2 & 7,1 & $7,9^{* *}$ \\
\hline & $\begin{array}{l}\text { - фінанси } \\
\text { страхування }\end{array}$ & 4,6 & 5,4 & 6,1 & 6,3 & 7,0 & 8,6 & 10,2 & 12,9 & 16,5 \\
\hline & - IKT & 3,2 & 3,7 & 4,3 & 4,7 & 5,2 & 7,1 & 9,5 & 12,0 & 15,1 \\
\hline & - торгівля & 1,8 & 2,4 & 2,7 & 3,0 & 3,4 & 4,5 & 5,8 & 7,6 & 9,6 \\
\hline & - будівництво & 1,8 & 2,3 & 2,5 & 2,7 & 2,9 & 3,6 & 4,7 & 6,2 & 8,5 \\
\hline & - промисловість & 2,6 & 3,1 & 3,5 & 3,8 & 4,0 & 4,9 & 5,9 & 7,6 & 10,2 \\
\hline & - сільське господарство & 1,4 & $\overline{1,8}$ & 2,0 & 2,3 & 2,5 & 3,1 & 3,9 & 5,8 & 7,6 \\
\hline
\end{tabular}

Примітка: *дані наведено за 3 квартали 2018 року; **дані наведено станом на листопад 2018 р. Джерело: складено за даними [6; 7]

3 табл. 1 видно, що розрахункові показники-стимулятори, такі як валовий внутрішній продукт на душу населення та середня заробітна плата одного працівника, характеризуються помірним зростанням. Значення показників-дестимуляторів (індекс інфляції, рівень безробіття) або підвищуються протягом досліджуваного періоду, або суттєво не змінюються. Так, наприклад, індекс інфляції у період з 2010 р. по 2018 р. збільшився майже втричі (зі 149,9 \% до 391,2), що свідчить про загальне зростання рівня споживчих цін та поступове знецінення національної валюти. 
Діяльність видавничо-поліграфічних підприємств здебільшого орієнтована на В2В сегмент. Тому необхідною умовою формування та реалізації конкурентних переваг типографій та видавництв $\epsilon$ не лише загальна макроекономічна стабільність країни, але й економічне становище підприємств інших видів діяльності (різних галузей промисловості, а також сфери послуг). Це твердження пояснюється тим, що створення та утримання конкурентних переваг відбувається більш ефективно тоді, коли на підприємстві забезпечено необхідний мінімум - налагоджено механізм безперебійного виконання поточних операційних задач. При цьому надійність постачальників та замовників, їх фінансова стійкість та готовність швидко ліквідувати заборгованість по виставлених рахунках-фактурах $\epsilon$ основним чинником формування грошової маси виконавця поліграфічних послуг.

Економічне становище підприємств України може бути характеризоване 3 використанням таких показників, як частка прибуткових підприємств, рентабельність операційної діяльності, обсяг реалізованої продукції та ін. (табл. 2). Аналіз динаміки показників підприємств України надасть можливість сформулювати висновки про потенційні загрози розвитку бізнесу та визначити резерви їх подолання.

Таблиця 2 - Основні показники діяльності підприємств України за період 2010-2017 pp.

\begin{tabular}{|c|c|c|c|}
\hline \multirow{2}{*}{ Рік } & $\begin{array}{c}\text { Частка прибуткових } \\
\text { підприємств, \% }\end{array}$ & $\begin{array}{c}\text { Рентабельність операційної } \\
\text { діяльності, \%, в середньому за рік }\end{array}$ & $\begin{array}{c}\text { Обсяг реалізованої } \\
\text { продукції, млрд. } \\
\text { грн }\end{array}$ \\
\hline 2010 & 60,1 & 4 & 3366,2 \\
\hline 2011 & 59,2 & 5,9 & 3991,2 \\
\hline 2012 & 64,5 & 5 & 4203,2 \\
\hline 2013 & 65,9 & 3,9 & 4050,2 \\
\hline 2014 & 66,3 & $-4,1$ & 4170,7 \\
\hline 2015 & 73,7 & 1,0 & 5159 \\
\hline 2016 & 73,4 & 7,4 & 6237,5 \\
\hline 2017 & 72,8 & 8,8 & 7708 \\
\hline 2018 & 70,8 & 7,9 & $\ldots$ \\
\hline
\end{tabular}

Джерело: складено за даними [8; 9; 10]

3 даних табл. 2 видно, що більшість підприємств України були прибутковими протягом 2010-2017 рр. Проте більш детальний аналіз статистичних даних [8] показав, що обсяг збитку неприбуткових компаній може перевищувати отримані прибутки. Так, наприклад, у 2014 році, коли збитки значно (у 2,6 раза) перевищили отримані економічні вигоди, зведений фінансовий результат склав $-523587,0$ млн грн. До 2016 року ця розбіжність поступово зменшилася, але фінансовий результат залишався від'ємним та складав у 2015 році -340126,6 млн грн., у 2016 році відповідно $-22201,50$ млн грн. Починаючи з 2017 року в Україні зафіксовано додатній 
фінансовий результат на рівні 274831,6 млн грн. у 2017 році та 208238,1 мнл грн. у 2018 році.

Згідно даних табл. 2, протягом останніх 9 років, окрім 2014 р., операційна діяльність суб'єктів господарювання була рентабельною, а відповідний коефіцієнт коливався від 1,0 до 8,8 \%. У 2014 році, після загострення економіко-політичного конфлікту, що розпочався у листопаді 2013 р., зафіксована збитковість бізнесу, а середній показник рентабельності склав $\quad-4,1 \%$. Окрім того, детальний аналіз даних [9] надає підстави стверджувати, що найбільших втрат 2014 року зазнали саме малі за розміром підприємства, збитковість яких сягнула 17,9 \%. Натомість, великі компанії зберегли перевищення доходів над витратами навіть у кризовий рік, відновивши фінансові результати вже у 2015 році (рис. 1).

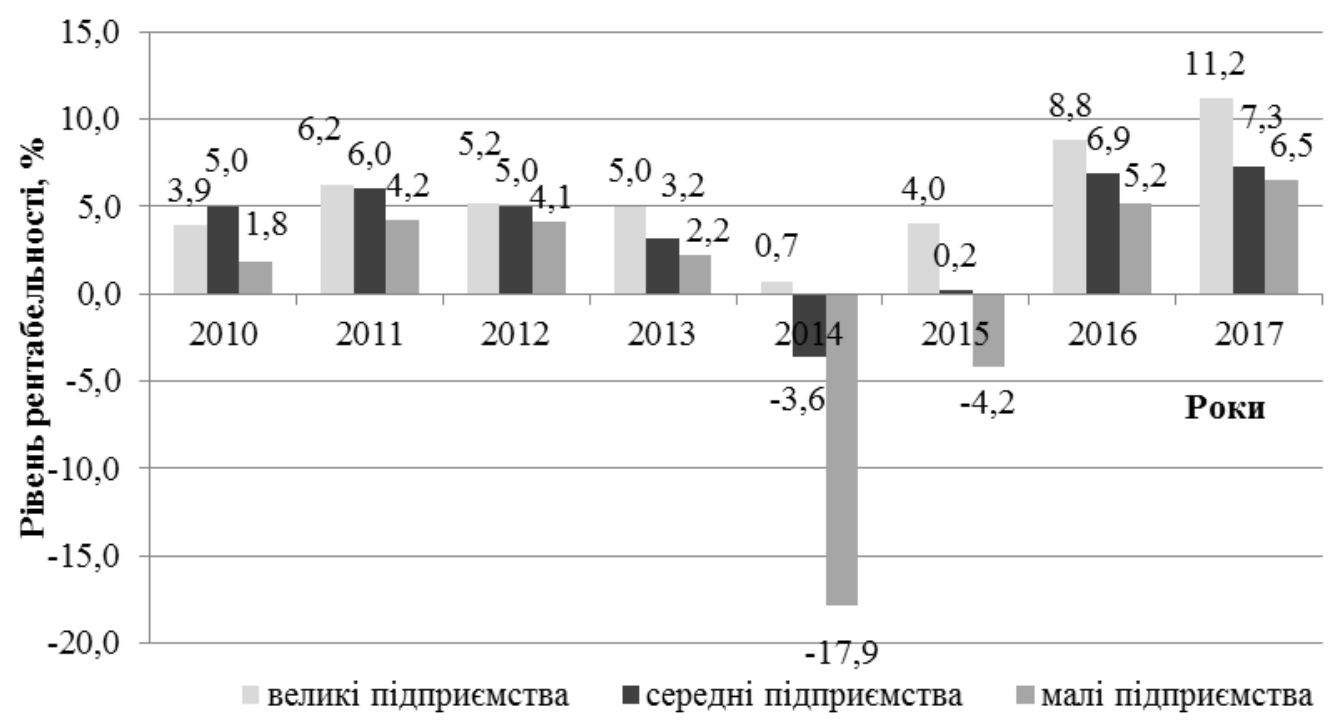

Рисунок 1 - Динаміка показника рентабельності операційної діяльності підприємств України за період 2010 - 2017 рр. Джерело: складено за даними [9]

Аналізуючи обсяги реалізованої продукції в Україні за період 2010-2017 pp. [10], можна зробити висновок про значний внесок великих та середніх підприємств в національний товарний оборот. Так, у 2010 році зафіксовано рівні частки представників великого та середнього бізнесу в обсягах реалізованої продукції - 40,6 та 40,5 \% відповідно, а малим компаніям належить лише 16,9\%. У 2017 році частки середніх та малих підприємств збільшились та склали відповідно 42,8 \% та 19,2\%.

На основі отриманих результатів проведеного аналізу можна сформулювати наступні висновки:

- починаючи 32015 року відбувається поступове відновлення економічного становища підприємств України. Це є позитивним чинником формування та реалізації конкурентних переваг видавничо-поліграфічних підприємств, оскільки збільшуються можливості співпраці із клієнтами щодо забезпечення їх друкованою продукцією рекламного характеру; 
- привабливою цільовою групою для надання видавничополіграфічних послуг можуть стати малі прибуткові компанії, котрі прагнуть збільшити обсяг реалізованої продукції за рахунок інтенсифікації реклами.

II. Фінансові детермінанти. Впровадження якісних змін у діяльність видавничо-поліграфічних підприємств можливе у випадку наявності необхідних та достатніх фінансових ресурсів. Належного фінансування потребує як друкарське обладнання, котре має відповідати трендам ринку поліграфічної продукції, так і програмне забезпечення бізнес-процесів на усіх етапах виробничого циклу. Окрім впевненості у сприятливому економічному становищі контрагентів, для видавничо-поліграфічного підприємства важливо адекватно оцінювати власні можливості щодо фінансового самозабезпечення, особливо у період здешевлення національної валюти та підвищення рівня світових цін.

За результатами досліджень Р. Девіса, які представлено в аналітичному звіті [11], основним чинником економічної ефективності поліграфічних підприємств є управління виробничими витратами, зокрема мінімізація їх рівня. Проте фінансовий менеджмент вітчизняного поліграфічного бізнесу ускладнюється в умовах неоднорідної структури собівартості друкованої продукції, а саме високої (іноді до 80 \% вартості готового виробу) ціни на папір. 3 урахуванням динаміки світових цін на папір та інші матеріали виникає необхідність пошуку шляхів оптимізації товарної структури у бік зменшення матеріаломісткості виробництва.

Здатність накопичувати та ефективно використовувати фінансові ресурси є необхідною умовою створення цільових фондів. Стратегічного значення набуває поповнення фондів, цільовим призначенням яких $\epsilon$ розширення виробництва. Разом 3 тим, процеси накопичення перебувають під постійним негативним впливом коливання курсу валют. Внаслідок цього, дохід, отриманий від надання поліграфічних послуг на внутрішньому ринку, може бути не достатнім для одночасного покриття витрат, пов'язаних із імпортом сировини та матеріалів, та забезпечення належного рівня рентабельності продажу. Коливання курсу валют визнано одним з основним чинників, що стримують конкурентоспроможність поліграфічних підприємств, згідно опитування, проведеного аналітиками Print+ [12]. В Україні тенденція зміни курсових різниць (рис. 2) свідчить про стійку несприятливу фінансову ситуацію, порівняно із країнами з відносно високим рівнем міжнародної конкурентоспроможності. 


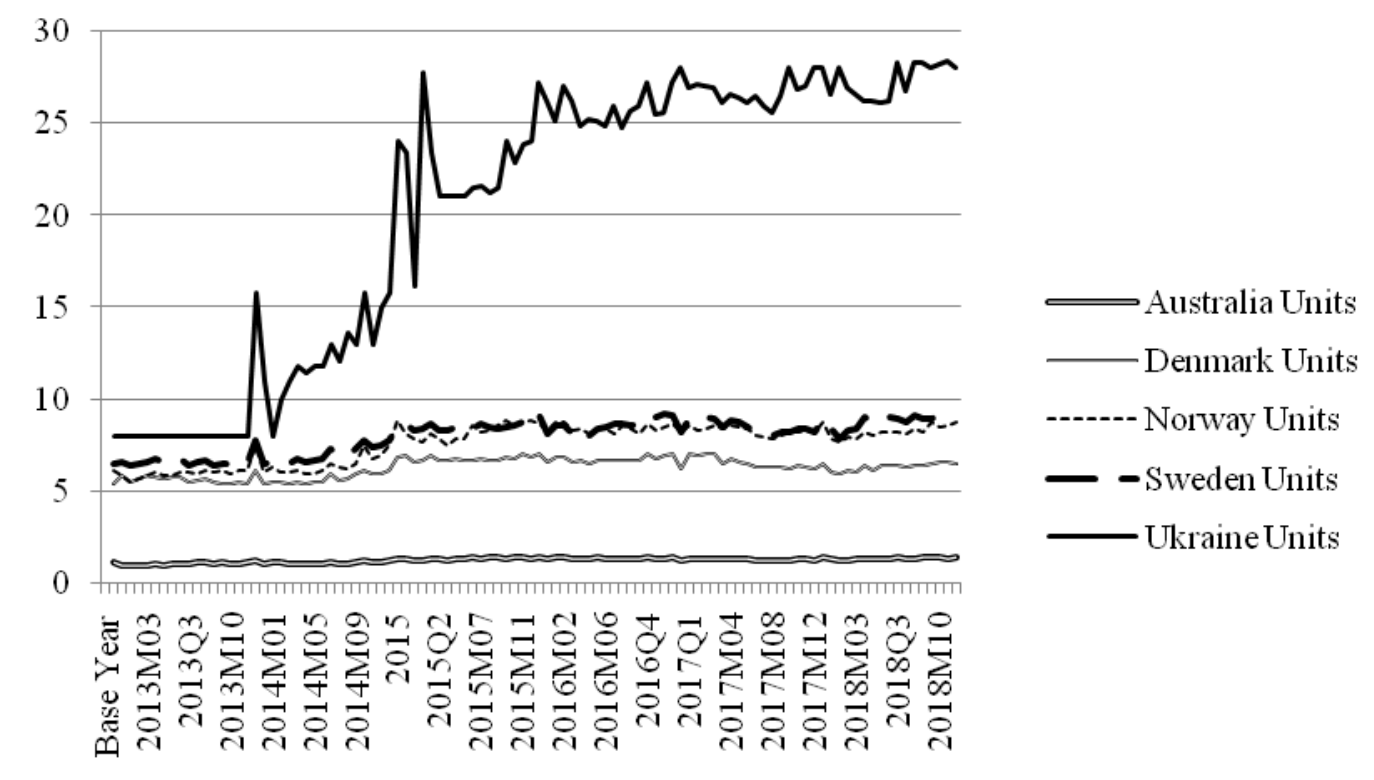

Рисунок 2 - Динаміка курсу національної валюти до долара США у країнах світу. Джерело: складено за даними [14]

Аналіз результатів опитування [13] надає підстави стверджувати, що саме фінансовий чинник визначає можливість економічного процвітання більшості видавничо-поліграфічних підприємств світу. При цьому, більшість опитаних компаній, у тому числі друкарні та постачальники поліграфічних матеріалів повідомили про зростання витрат на операційну діяльність відзначили стале підвищення операційних витрат протягом останніх років. Серед регіонів світу найбільш позитивними тенденціями 3 фінансового забезпечення діяльності поліграфічних підприємств характеризується Північна Америка. Найменш прогнозовані показники мають підприємства Центральної Європи, оскільки саме в цьому регіоні зафіксовано суттєве (близько $50 \%$ ) зменшення маржинального доходу у 2017 році у порівнянні із попереднім періодом, не зважаючи на підвищення виручки від реалізації продукції. Загалом, попри те, що 30 \% респондентів відзначили зниження попиту та середніх цін на продукцію та послуги з друку, за результатами опитування можна стверджувати про позитивні очікування поліграфічних підприємств в усіх регіонах світу щодо фінансового стану у найближчі роки.

В Україні одним із фінансових детермінантів економічного розвитку поліграфічних підприємств $\epsilon$ оптимізація структури їх витрат. Згідно даних досліджень [15, с. 214-215; 16], найбільшу частку у загальному обсязі видатків займають матеріальні витрати (близько 70 \%) та витрати на оплату праці персоналу (до 17 \%); найменша частка належить амортизаційним витратам. 


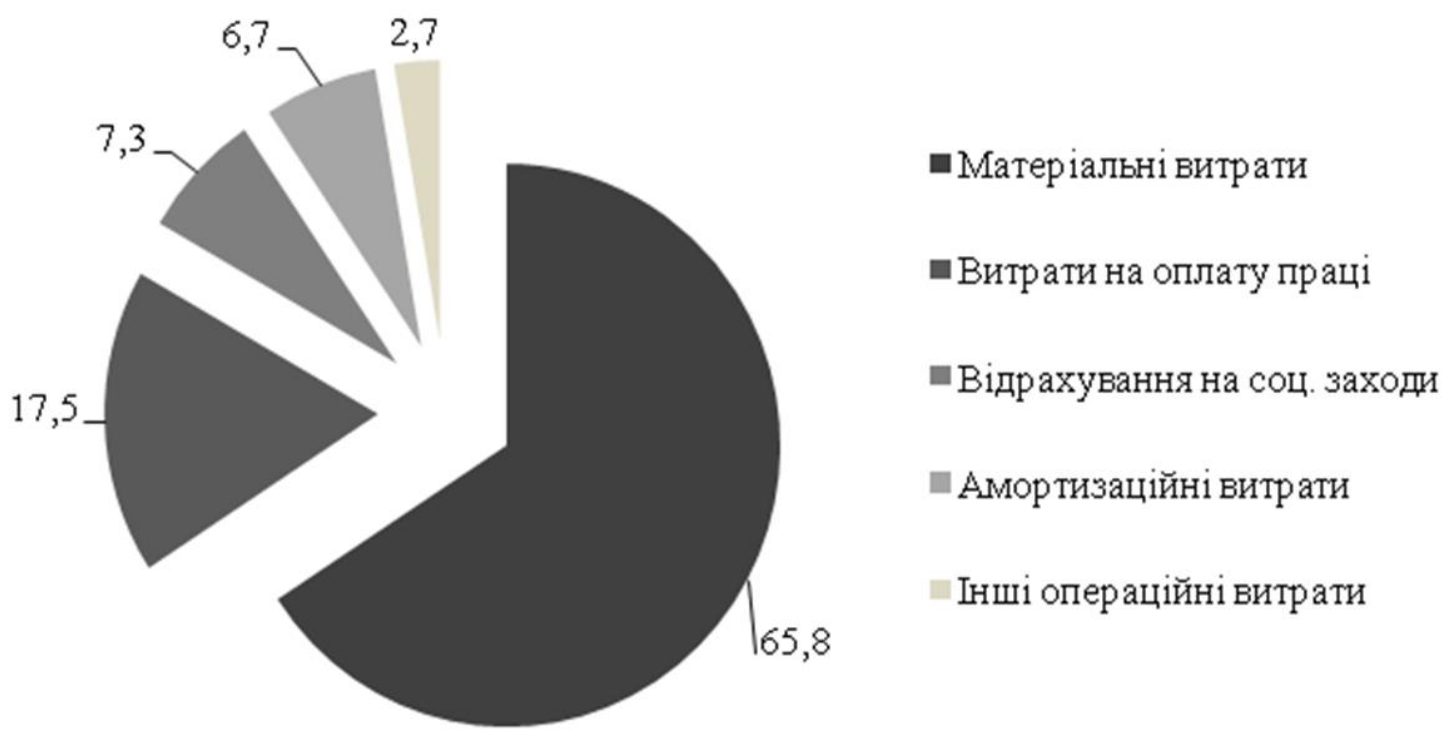

Рисунок 3 - Структура операційних витрат видавничо-поліграфічних підприємств. Джерело: складено на основі матеріалів [15; 16]

3 урахуванням структури, представленої на рис. 3, задля підвищення конкурентоспроможності, зокрема при реалізації конкурентної стратегії лідерства за витратами, доцільним є пошук шляхів оптимізації витрат на матеріальне забезпечення та формування фонду заробітної плати. Важливо зазначити, що мінімізація обсягу витрат не завжди $є$ метою управління видатками ресурсномістких виробництв, оскільки може призвести до суттєвого зниження якості продукції. Так, закупівля порівняно дешевого паперу призведе до зниження зносостійкості та довговічності брошури чи каталогу або до зниження привабливості комерційних листівок через видозміну передачі кольору. Тому важливим $є$ не стільки зменшення обсягу витрат, скільки їх раціоналізація, коли кошти спрямовуються на стратегічно важливі заходи та зменшуються на тактичні переваги.

Одним зі складних завдань та важливим фінансовим детермінантом конкурентоспроможності підприємств є управління витратами на оплату праці персоналу. Аналогічно до матеріальних витрат, фонд оплати праці недоцільно мінімізувати, коли існує ризик зниження продуктивності або якості праці. Так, оплата праці персоналу на деяких посадах (перелік найбільш поширених представлено у табл. 3) потребують особливої уваги через те, що власне забезпечують основні поліграфічні процеси. 
Таблиця 3 - Рівень заробітних плат на поліграфічних підприємствах на початок 2019 p.

\begin{tabular}{|c|c|c|c|}
\hline $\begin{array}{l}\text { № } \\
\Pi / \Pi\end{array}$ & Назва посади & Основні здачі персоналу & $\begin{array}{c}\text { Рівень } \\
\text { заробітної } \\
\text { плати, тис. } \\
\text { грн.* } \\
\end{array}$ \\
\hline 1 & Головний технолог & $\begin{array}{c}\text { Техніко-технологічний супровід } \\
\text { поліграфічних процесів }\end{array}$ & $12-23$ \\
\hline 2 & Начальник виробництва & $\begin{array}{c}\text { Організаційно-управлінське } \\
\text { забезпечення передачі та виконання } \\
\text { замовлень }\end{array}$ & $12-25$ \\
\hline 3 & $\begin{array}{l}\text { Оператор станку офсетного } \\
\text { друку }\end{array}$ & $\begin{array}{c}\text { Виконання замовлень додрукарського } \\
\text { цеху з офсетного друку }\end{array}$ & $8-12$ \\
\hline 4 & $\begin{array}{l}\text { Оператор станку } \\
\text { шовкотрафаретного друку }\end{array}$ & $\begin{array}{c}\text { Виконання замовлень додрукарського } \\
\text { цеху з шовкотрафаретного друку }\end{array}$ & $8-12$ \\
\hline 6 & Оператор 3D принтера & $\begin{array}{c}\text { Виконання замовлень додрукарського } \\
\text { цеху з 3D друку }\end{array}$ & $10-20$ \\
\hline 7 & $\begin{array}{l}\text { Спеціаліст додрукарської } \\
\text { підготовки }\end{array}$ & $\begin{array}{c}\text { Опрацювання макетів друкованої } \\
\text { продукції, технічна допомога } 3 \\
\text { макетування } \\
\end{array}$ & $8-14$ \\
\hline 8 & Дизайнер-ілюстратор & $\begin{array}{c}\text { Створення комерційних зображень } \\
\text { (логотипи, зображення для пакування, } \\
\text { технічний дизайн) }\end{array}$ & $8-30$ \\
\hline 9 & Дизайнер зі шрифтів & $\begin{array}{c}\text { Розробка унікальних друкарських } \\
\text { шрифтів для логотипів та комерційних } \\
\text { назв } \\
\end{array}$ & $10-30$ \\
\hline 10 & Акаунт-менеджер & Комплексний супровід замовників & $15-30$ \\
\hline 11 & Спеціаліст із логістики & $\begin{array}{c}\text { Оптимізація логістичних маршрутів } \\
\text { (транспорт та виробництво) }\end{array}$ & $10-16$ \\
\hline 12 & Макретолог/SMM-менеджер & $\begin{array}{l}\text { Розробка маркетингової кампанії, } \\
\text { просування поліграфічних послуг }\end{array}$ & $8-20$ \\
\hline 13 & Редактор/коректор текстів & $\begin{array}{c}\text { Опрацювання/вивірення текстової } \\
\text { частини замовлень }\end{array}$ & $8-12$ \\
\hline 14 & Спеціаліст репроцентру & Проведення кольорових проб & $8-12$ \\
\hline
\end{tabular}

Примітка: * дані для м. Києва станом на 01.02.2019 p.

Джерело: складено автором на основі [17; 18]

3 табл. 3 видно, що найвищого рівня може сягати заробітна плата працівників, котрі займають такі посади: головний технолог, начальник виробництва, дизайнер-ілюстратор, дизайнер зі шрифтів, акаунт-менеджер. Таким чином, при плануванні умовно-прямих витрат варто приділити увагу аналізу можливості заміни штатних працівників фріланс-спеціалістами, а відповідні трудові контракти на договори надання послуг суб'єктами підприємницької діяльності. Так, якщо для виконання поставлених задач працівникові необхідне лише автоматизоване робоче місце, то доцільно розглянути можливість створення дистанційних робочих груп/відділів тощо. При цьому важливо враховувати, які спеціалісти беруть безпосередню участь 
у створенні доданої вартості. Саме такі спеціалісти потребують комплексного підходу до планування витрат на оплату праці: переведення їх на дистанційну роботу або заключення договору про надання послуги в умовах зниження рівня поточного контролю може вплинути на продуктивність праці та якість виконання замовлень, а отже на рівень конкурентоспроможності підприємства.

Висновки. Проведене дослідження надало можливість вирішити наукове завдання з розвитку теоретичних та прикладних аспектів визначення детермінантів підвищення конкурентоспроможності видавничополіграфічних підприємств в умовах економічної нестабільності, зокрема, узагальнити особливості макроекономічного та фінансового забезпечення підвищення конкурентоспроможності видавничо-поліграфічних підприємств.

Наукова новизна результатів дослідження полягає в узагальненні особливостей макроекономічних та фінансових детермінантів підвищення рівня конкурентоспроможності видавничо-поліграфічних підприємств на основі врахування екзогенних непідконтрольних та ендогенних підконтрольних чинників економічного середовища підприємств та можливості зменшення дії негативних фінансових чинників за рахунок оптимізації структури фонду заробітної плати через створення дистанційних проектних команд.

Перспективним напрямом подальших досліджень $\epsilon$ оцінювання економічної ефективності створення дистанційних проектних команд на видавничо-поліграфічних підприємствах 3 метою протидії негативному впливу фінансових чинників-дестимуляторів конкурентоспроможності.

\section{Література:}

1. Doing Business 2019. Training for Reform : report. International Bank for Reconstruction and Development. Washington DC, 2019. 311 p.

2. Doing Business 2018. Reforming to Create Jobs : report. International Bank for Reconstruction and Development. Washington DC, 2018. 312 p.

3. Очікування підприємств сфери послуг у IV кварталі 2018 року щодо перспектив розвитку їх ділової активності : статистичний звіт. Державна служба статистики України, 2018. URL: http://www.ukrstat.gov.ua/. Дата звернення: 15.01.2019

4. Kukharuk A., Gavrish Yu., Zmitrovych D. Managing the competitiveness in CIS countries and Ukraine: the goal and conditions. Eastern Journal of European Studies. 2017. Is 8(1). pp. $115-136$.

5. Schwab K. et al. The Global Competitiveness Report 2017-2018. Geneva : World Economic Forum, 2017. 381 p. URL: http://www3.weforum.org/docs/GCR20172018/05FullReport/TheGlobalCompetitivenessReport2017\%E2\%80\%932018.pdf. Дата звернення: 10.01 .2019

6. Макроекономічні показники : статистична інформація. Національний банк України. Офіційний сайт національного банку України, 2019. URL: https://bank.gov.ua/control/uk/publish/article?art_id=23487024. Дата звернення: 13.01 .2019 p.

7. Индексы : Номинальный ВВП Украины с 2002 по 2018 гг. Мінфін: фінансовий портал. URL: https://index.minfin.com.ua/economy/gdp/ Дата звернення: 13.01 .2019 p. 
8. Фінансові результати підприємств до оподаткування за видами економічної діяльності : статистична інформація. Державна служба статистики України, 2018. URL: http://www.ukrstat.gov.ua/. Дата звернення: 17.01.2019

9. Рентабельність операційної та усієї діяльності підприємств за видами економічної діяльності з розподілом на великі, середні, малі та мікропідприємства (20102017) : статистична інформація Державна служба статистики України, 2018.URL: http://www.ukrstat.gov.ua/. Дата звернення: 18.01.2019

10. Обсяг реалізованої продукції (товарів, послуг) підприємств за видами економічної діяльності з розподілом на великі, середні, малі та мікропідприємства (20102017) : статистична інформація Державна служба статистики України, 2018. URL: http://www.ukrstat.gov.ua/. Дата звернення: 18.01.2019

11. Davis R. Print Management Alert. Impact of Cost on Profitability in the Printing Industry : report. USA : Printing Industries of America, Center for Print Economics and management, 2017. 8 p. URL: https:/www.printing.org/sites/default/files/ attachments/management_alert-cost_and_profits_final_after_edits_sept_2017.pdf. Дата звернення 19.01.2019

12. Какой будет полиграфия Украины в 2018 году. Итоги январского блиц-опроса журнала Print+. URL: https://printus.com.ua/article/read/3571 Дата звернення: 20.12.2018

13. $5^{\text {th }}$ drupa Global Trends Report 2018. Executive summary. URL: https://www.drupa.com/cgi-bin/md_drupa/lib/all/lob/return_download.cgi/5th_

Global_Trends_Executive_Summary_EN.pdf?ticket=g_u_e_s_t\&bid=4016\&no_mime_type=0 Дата звернення 25.01.2019

14. Exchange Rates incl. Effective Ex. Rates : Data Tables. International Monetary Fund. URL: http://data.imf.org/regular.aspx?key=61545862

15. Сосновська О. О., Жидецька Х. В. Сучасні проблеми управління витратами на підприємствах видавничо-поліграфічної галузі. Наукові записки : наук.-техн. зб. Сер.: Економічні науки. 2016. № 2 (53). С. 213-220.

16. Должанський А. М. Облік і контроль виробничих витрат у поліграфії (на матеріалах малих підприємств західного регіону україни): автореф. дис. на здобуття наук. ступеня канд. екон. наук : спец. 08.06.04 „Б Бухгалтерський облік, аналіз і аудит ”. Львів, 2002. 19 с.

17. Офіційний сайт порталу вакансій Rabota.ua. URL: https://rabota.ua/ua. Дата звернення: 01.02.2019

18. Офіційний сайт порталу вакансій Work.ua. URL: https://www.work.ua/. Дата звернення: 01.02.2019

19. Гавриш О. А., Кухарук А. Д. Генерація імпульсів формування належного рівня конкурентоспроможності поліграфічних підприємств. Економічний вісник Начіонального технічного університету Украӥни «Київський політехнічний інститут»: зб. наук. пр. 2013. № 10. C. 134-139.

20. Юдіна Н. В., Солнцев С. О. Особливості рекламної діяльності виробника рекламно-поліграфічної продукції. Проблеми системного підходу в економіці: електрон. наук. фах. вид. 2008. № 3. URL: http://www.nbuv.gov.ua/e-journals/PSPE/20083/Udina_308.htm.

21. Дурняк Б. В., Штангрет А. М., Мельников О. В. Видавничо-поліграфічна галузь України: стан, проблеми, тенденції. Статистично-графічний огляд. $\quad$ Л. : УАД, 2006. $274 \mathrm{c}$.

22. Довгань Л. Є., Воржакова Ю. П. Механізм формування конкурентної політики поліграфічних підприємств. Актуальні проблеми економіки. 2014. № 4(154). С. 32-40.

23. Палига Є. М. Реструктуризація підприємств видавничо-поліграфічної галузі як основа стратегії конкурентоспроможності і розвитку корпоративного управління. Вісник економічної науки України. 2016. № 2. С. 143-148. 
24. Davis R. Print Management Alert. Impact of Cost on Profitability in the Printing Industry : report. - USA : Printing Industries of America, Center for Print Economics and management, 2017. 8 p. Retrieved from: https://www.printing.org/sites/default /files/attachments/management_alert-cost_and_profits_final_after_edits_sept_2017.pdf. Дата звернення 19.01.2019

25. Какой будет полиграфия Украины в 2018 году. Итоги январского блиц-опроса журнала Print+. URL: https://printus.com.ua/article/read/3571 Дата звернення: 20.12.2018

УДК 658.330

JEL classification: Q56

Коцко Т.A.

канд. економ. наук, доиент ORCID ID: 0000-0002-0111-0784

Національний технічний університет Украӥни «Київський політехнічний інститут імені Ігоря Сікорського»

\section{ПОЛІТИКА ЕКОЛОГІЗАЦІЇ ДІЯЛЬНОСТІ ПДПРИЕМСТВ ПАЛИВНО-ЕНЕРГЕТИЧНОГО КОМПЛЕКСУ: ПРОБЛЕМИ ФОРМУВАННЯ ТА РЕАЛІЗАЦІЇ}

\section{THE POLICY OF ENVIRONMENTAL ACTIVITY OF ENTERPRISES OF FUEL AND ENERGY COMPLEX: THE PROBLEMS OF FORMATION AND REALIZATION}

У статті розглянуто проблеми екологізації діяльності підприємств паливноенергетичного комплексу у контексті формування передумов забезпечення їх екологоекономічної ефективності та конкурентоспроможності. Досліджено особливості трансформації паливно-енергетичного комплексу України, його структуру, проблеми розвитку. Доведено залежність прочесів макроекономічних трансформацій від ефективності трансформацій галузей паливно-енергетичного комплексу. Розкрито механізми впливу підприємств паливно-енергетичного комплексу на навколишнє природне середовища, а також екологічні $i$ економічні наслідки такого впливу. Розглянуто сутність політики екологізаџї діяльності підприємства, об'єкти та напрями екологізації, ї̈ переваги та роль у забезпеченні розвитку підприємства. Визначено причини відсутності мотивів формування політики екологізації підприємствами паливноенергетичного комплексу. Проаналізовано правову базу формування екологічної політики в Украӥні, екологізачії економічного розвитку. Встановлено, щуо практичне втілення принципів екологічної політики у господарську практику підприємств ускладнюється проблемами інституційного характеру. Розкрито багатоаспектний та суперечливий характер поняття «екологізація», який відображає тендениії розвитку сфери природокористування в цілому. Доведено, щуо екологізація - ие інструмент, який дозволяє мінімізувати еколого-економічні збитки на рівні підприємства, формує передумови інновачійного розвитку підприємства та його стратегічної конкурентоспроможності. Охарактеризовано моделі політики екологізації $з$ урахуванням рівня розвитку організаційної культури підприємств та можливостей їі реалізації. Запропоновано підхід до вибору моделі екологізаиії діяльності сучасного підприємства. Обтрунтовано напрями та інструменти реалізації політики екологізації підприємств паливно-енергетичного комплексу. 